\title{
Discursive Stratagems: Ambrose Bierce's Attacks on Realism's Metaphysics of Language
}

\author{
Aitor Ibarrola Armendariz \\ Universidad de Deusto
}

Language, $n$. The music with which we charm the serpents guarding another's treasure. (Ambrose Bierce, The Devil's Dictionary)

The dialogical orientation is obviously a characteristic phenomenon of all discourses. It is the natural aim of all living discourse. Discourse comes upon the discourse of the other on all roads that lead to its object, and it cannot but enter into intense and lively interaction with it. Only the mythical and totally alone Adam, approaching a virgin and still unspoken world with the very first discourse, could avoid this mutual reorientation with respect to the discourse of the other, that occurs on the way to the other. (Mikhail Bakhtin, "Discourse in the Novel")

\begin{abstract}
This article explores the stylistic devices and narrative techniques that the late 19 thcentury great American satirist employed to subvert and ridicule his contemporaries' understanding of language and of $i$ ts relationship to reality. According to Bierce, language is not merely a constative and aseptic means to represent the world around us and communicate ideas. On the contrary, all discourses are loaded with a great deal of power and knowledge which make them about the most effective-and dangerous-performative instruments in our culture. By drawing assiduously from the writings of such theorists as Bakhtin, Foulcault, or Kristeva, this critical piece tries to demonstrate that Bierce's charges against realism allegedly neutral utilization of language were well-grounded. In order to do so, the dialogic character, parodic tone, and effective stylization of two of
\end{abstract}


Bierce's best-known stories, "Chickamauga" and "My Favourite Murder," are studied in some depth. By the end of the article, the reader should have recognized a number of the reasons for Bierce's attested "obscurity" in his own days and after.

Ambrose G. Bierce's outstanding curriculum as a man of arms and cartographer for the Federal Army during the Civil War leaves little doubt as to his ability to devise the most effective strategies and plans of action on the battlefield. ${ }^{1}$ His war stories and "Bits of Autobiography" also evince a particularly acute eye for depicting and "reading" closely different terrains to turn them into the most appropriate backgrounds for his fiction and personal experiences. Nevertheless, what interests us here is not so much Bierce's talents in the bellicose enterprise as his proficiency in discerning some weak flanks in the ideology of the literary establishment of his day and his relentless assaults on what he estimated to be realism's most unpardonable betrayal of reality.

Despite the atmosphere of discontent and frustration that prevailed in a large part of the American society during the last two decades of the 19th century, and which emerges obliquely in such utopian novels of the period as Twain's A Connecticut Yankee in King Arthur's Court, Bellamy's Looking Backward or Howell's A Traveller from Altruria, no writer seemed to question the adequacy of the discursive practices that served as deeplyrooted pillars for the configuration and development of an identity in the new nation. I intend to show in this article that Bierce's short narratives represent unconventional and often sanguinary attacks on a metaphysics of language that only much later-possibly beginning after World War II-has proved at least dubious, if not utterly inconsistent, with respect to the reality that it tries to render. ${ }^{2} \mathrm{I}$ also demonstrate that many of the responses to his works have been biased by very much the same misconceptions his stories are designed to reveal. If it is a fact that reading Bierce requires quite a different kind of perceptual framework in order to perceive his most profound intricacies, it is also clear that the awareness one may gain of how we are always victimized by the discourse of "the Other" is well worth the effort. ${ }^{3}$

For variety's sake, on the one hand, but most importantly to give a sense of how those subversive strategies pervade the bulk of Bierce's literary production, I have chosen two stories belonging to two different collections: "Chickamauga" (Ch) from In the Midst of Life (1891) and "My Favourite Murder" (MFM) from Can Such Things Be? (1893). Predictably, in both of them we are presented with a typically Biercean picture of reality: mishaps, human folly, desperation and deaths are depicted with such a degree of cool detachment and objectivity that the reader is almost compelled to accept that this must be the common condition of humankind. Yet, I believe that, contrary to what a majority of scholars have argued, the object of the satire in these short stories is not, or to be more precise not only, the brutality of war, the emptiness of religious and philosophical teleologies, or the injustice of the judicial system. ${ }^{4}$ Rather, a closer reading of his tales reveals a covert genealogy of several discourses that tries to bring us upon the ultimate sources of those expressions of human dissolution and disintegration. At the root of the problem, we discover an understanding of language as an overriding factor in all our 
behaviours; but even more to the point, language or rather a series of discourses as the prisms through which we perceive, interpret and evaluate the universe around us.

If Bierce proves to excel most of his contemporaries in his awareness of the problems posed by accepting reality at face value, what really places him above the rest is his consciousness of the fallaciousness of language as presence. As will be seen, in his stories, discourse becomes a coin everyone reveres for its halo of power, only to find out eventually, in his hyperdramatic epiphanies, that besides being pragmatically deceitful, it has sucked out in the process of its reification the little substance that there was in the user. Of course, in order to come to grips with these ideas, one needs to shift the focus of attention from the story level of the narratives to that of discourse. ${ }^{5}$

It is only then that we begin to realize that attitudes and voices are activated not so much as a result of some previous experiences but rather as echoes of diverse speech acts which have been absorbed by the characters and narrators. Thus, the text cannot be understood any longer as an autonomous organism, to be dissected and analyzed as such, but rather as simply one more participant in a dialogic scenario. It is needless to say that the contributions of Mikhail Bakhtin and Hans R. Jauss offer adequate methodological tools to elucidate how this change of perspective may throw new light onto our understanding of Bierce's oeuvre. ${ }^{6}$

This newly-opened dialogue between reader, text and history will constantly make us unearth questions about the (in)stability of certain discursive practices and their (in)adequacy to capture the ontologico-epistemological essences of the surrounding universe. It seems important to remark at the outset that the central characters of the two narratives under analysis are a deaf-mute child and a seemingly insane parricide-personages who, in their inability to give shape to their selfhoods, resort to alien discourses that obviously do nothing but deform and twist them into even more grotesque figures. It would be more difficult to determine in these two stories to what extent Bierce may be conveying the idea that, in one way or another, we are all easy preys to some language conventions that inevitably demarcate our existence. This is not the type of naturalism that we are familiar with but it comes in several ways to show just how much ahead of his time Bitter Bierce was in his views on the deployment of discourse, knowledge, and power. ${ }^{7}$

Bierce was always well aware of his fate to become the American literary "obscurian" par excellence. Like Robert Frost and so many other illustrious artists in the United States, he "took [the road] less travelled by,/and that [of course] has made all the difference" (223). Attempts to rediscover him have been fairly numerous in our century but, more often than not, critics have failed to integrate his works into the broader stream of the literature of his day. Moreover, only too rarely have they found a suitable approach to his works that would allow them to appreciate their true significance. No doubt, Bierce's attitude toward fame and recognition did not help much either. He was proud and even defiant about his status as a non-belonger and often boasted that: "My independence is my wealth, it is my 
literature" (qtd. in Neale 97). Now, if he was right in this belief, would it not be unfair to try to "canonize" him by drawing comparisons with his contemporary literati? Should not his production be studied in vacuo, as most critics have done until now? Would it be the correct step to try to frame a non-conformist within the system of moral and literary values that he himself continually abused?

Despite the degree of dissociation that an author may consciously achieve, it is quite evident that he always remains a nursling to his own period. A writer's production can hardly be studied in its full dimension by alienating his works from the general literary paradigm that backgrounded them. As Jauss has pointed out, "a literary work, even if it seems new, does not appear as something absolutely new in an informational vacuum, but predisposes its readers to a very definite type of reception by textual strategies, overt and covert signals, familiar characteristics or implicit allusions" (12). So, be it as a belonger or as a reactionary to this overall frame that each literary period entails, an author ought to be studied against the other works being produced and read at the time. Failing to proceed thus, one may easily distort the horizon (of expectations) which the works were addressing and, consequently, make the text serve almost any particular purpose or ideology. Bierce, notwithstanding his own or some of his scholars' claims to the contrary, should in this sense also be subjected to a historico-literary contextualization for a more accurate diagnosis of his art. ${ }^{8}$ In fact, we shall observe below that some of his works' foremost features funneled him to the role of a more than active participant in the literary and non-literary debates of his day.

To begin with, Bierce, like most of his fellow writers in the last two decades of the 19th century, set out on his career as a man of letters in the pages of several newspapers and magazines. ${ }^{9}$ This fact undoubtedly left an indelible imprint on his style and on his approach to the themes covered in his stories. One could go so far as to assert that he was, from the start, condemned to make use of the techniques and show the frame of mind of the newsreporter. As Berthoff remarks in his well-known The Ferment of Realism about many of the writers of the period:

[They were] somewhat detached, yes-but also strictly dependent, as writers, upon the inexplicable mass and persistence of the world. Only in reaction against it do they function at all; they require its repetitive miseries and follies to keep them going. They are in the purest sense "men of the crowd", deeply and ravagingly out of sorts with what, day after day, they see before them, yet spellbound and otherwise voiceless. (77)

This is in effect the case with Bierce. However, Berthoff's view seems limited in a very significant way. Some of these writers, but especially Bierce, needed not only the referential world to feed on and thrive, but they sought just as urgently the language and meanings then in circulation. All of Bierce's tales show, in this regard, the reporter's twofold concern to perfect as much as possible both the accuracy of his vision and his mastery in merging the utterances of "the Lacanian Other" with his own discourse.

His narratives become, due to these journalistic orientations, much more dialogical and heteroglossic, in Bakhtin's use of these two terms.$^{10}$ His deep play takes place not only at the level of perceptions, with innumerable shifts in time and point of view, but also at that 
of word-usage as he transgresses the boundaries of the single, monologic context to turn it into a site of cultural debate. Let us look briefly at the opening lines of "Chickamauga" to see how the author reappropriates "the Other's" utterances to highlight motivations and conducts:

One sunny autumn afternoon, a child strayed away from its home in a small field and entered a forest unobserved. It was happy in a new sense of freedom from control, happy in the opportunity of exploration and adventure; for this child's spirit, in bodies of its ancestors, had for thousands of years been trained to memorable feats of discovery and conquest-victories in battles whose critical moments were the centuries, whose victors' camps were cities of hewn stone. From the cradle of its race it had conquered its way through two continents and passing the great sea had penetrated a third, there to be born to war and dominion as a heritage. ${ }^{11}$

The datum that the child abandons his homestead totally "unobserved" should have important implications for our reading of the story. Firstly, from this point on, the narrator will be looking at the surrounding world through the eyes of the protagonist. But further, the often unreliable perceptions of the child will come about as a result of an alien discourse that "serves" him to build up those (mis)perceptions. That one cannot easily assign the "original" authorship of these lines to the author himself is obvious from the fact that if there was something that Bierce would have never done, it would have been to glorify war. ${ }^{12}$ As in so many other passages in Bierce's tales, here language is turning double-voiced and polyvalent for, as Bakhtin explained about Dostoevsky, "the ultimate conceptual authority (the author's intention) is brought out, not in the author's direct speech, but by manipulating the utterances of another addresser, utterances intentionally created and deployed as belonging to someone other that the author" ("Discourse Typology" 179).

The political jingoism and military harangue in this first paragraph of the story mimic quite explicitly the discursive practices of the abundant patriotic editorials in the current dailies. One should not forget that the fin de siecle witnessed the emergence of the United States as a new world power and, in some instances, even as an imperialist nation. Bierce's articles in the San Francisco Examiner and the New York Journal in the last fifteen years of the 19th century wished to be an effective antidote to the exacerbated involutionism of his country in Cuba, the Phillipines and South Africa. ${ }^{13}$ My point here, however, is that his virulent disputes with the mass-media intelligentsia of his time found its locus not just in his newspaper columns but also in his literary works, although unquestionably in more subtle ways. Once we have become aware of these other utterances in his discourse, we automatically begin to realize that "any text is construed as a mosaic of quotations: any text is the absorption and transformation of another. The notion of intertextuality replaces that of intersubjectivity, and poetic language is read as at least double" (Kristeva 66, her italics). In this context, the reader learns progressively to read for an intention behind each speech act and to gauge the performative force of each utterance against the others. ${ }^{14}$

Bierce's career as a professional journalist gave him access to all kinds of first-hand information and, of course, this fact contributed a great deal to his development of a very 
special ear able to record the registers and implicit volitions of the representatives of the "factic" powers in his social milieu. He soon realized, prefacing somehow the Marxist critics of the beginning of our century, that language serves, if anything, the interests of some homogeneous classes. Like Bakhtin, he would have maintained in this regard that "language is not a neutral medium that passes freely and easily into the private property of the speaker's intentions; it is populated-overpopulated-with the intentions of others. Expropriating it, forcing it to submit to one's own intentions and accents, is a difficult and complicated process" (Todorov 294). Bierce was a master in the art of pigeonholing and reappropriating the discourse of "the Other" for his own purposes. Indeed, a story like "My Favourite Murder" proves to be first and foremost an archive of several styles of speech. Each one of these styles is conspicuously aware of the power waves irradiating from the institutional ossification of its meanings.

The story opens in a courtroom where the protagonist is being tried for the "atrocious" murder of his mother. The first lines of the narrative are fraught with the sort of diction and cadences that are characteristic among the rather hermetic circles of attorneys and judges. Curiously, despite the protagonist's attested guilt, the court exculpates him as their fossilized discourse and unnerving bureaucracy have become so self-centered that inquiries into the truthfulness or falsity of the statements are repeatedly ignored. The attorney even loses sight of the crimes that have brought the defendant to this trial and focuses on tangential miscarriages of the law that the average reader finds ridiculously inconsequential:

The district attorney said: "Your Honor, I object. Such a statement would be in the nature of evidence, and the testimony in this case is closed. The prisoner's statement should have been introduced three years ago, in the spring of 1881."

"In a statutary sense," said the judge, "you are right, and in the Court of Objections and Technicalities you would get a ruling in your favour. But not in a Court of Acquittal. The objection is overruled." (MFM 793)

In this context, it is clear that what is important is not so much whether one has in fact done right or wrong, but rather if one is able to manoeuvre successfully within the same discursive fields of the opponent. The author, then, is telling us graphically that "signification, the social creation of meanings through the use of formal signs, is a practical material activity; it is indeed, literally a means of production" (Williams 38). Language, as Bierce conceived it, was never totally aseptic, but became one of the main weapons each social group had with which to subdue the rest to its authority and subject them to their laws. Consequently, his tales, apart from depicting quite accurately the linguistic registers of his time, are also allegories of how particular discourses and types of knowledge come to saturate a whole culture and project categories onto every one of its individuals. Allon White describes this process of the social dissemination and reification of discourses as follows:

Every register is typification, a style, the bearer of specific socio-cultural intentions; at the same time register is the bearer of self-referential identity which we recognize as 
such. Registers cannot help advertising themselves. We recognize them as pertaining to certain groups and certain social activities, hence the registration of historical and social distinctions-not least power relations and hierarchies. (124)

Bierce's usage of the utterance of "the Other" in both his newspaper articles and more literary pieces, shows great insight into questions of the interestedness of a majority of discourses and, subsequently, into how there is always a notorious distance between those registers and the realities they attempt to control. In this sense, many of his short stories are often best approached as Barthesian "writerly texts," as they point to themselvesmore than to the world-as the ultimate referent to be taken into consideration in any analysis. ${ }^{15}$

Despite the heavy journalistic component in all of Bierce's works, it is quite patent to the average reader that his short narratives are far from being mere collections of quotations and citations from "the Other." A second feature in his writings, which I propose to explore now, will help us to unveil his ultimate animus in including these multidetermined utterances, which obviously never remain unmediated or unevaluated. If one were to choose a generic label for Bierce's stories as a whole, the first one to come to our minds would be very likely that of satire. In Frye's theory of myths, two components seem to be essential in this particular mythos: "one is wit and humor founded on fantasy or a sense of the grotesque or absurd, the other is an object of attack" (244). As we shall see, both ingredients are present in varying degrees in Bierce's narratives.

On the one hand, he is habitually grouped with the local color and tall-tale tradition of writers on the Western frontier of the United States, who became so very keen on the comic grain to aggrandize their sarcastic, and even apocalyptic, pictures of the current social and moral habitats (see especially Samuel Clemens and Bret Harte).${ }^{16}$ On the other hand, he grew to be America's great maestro at launching vituperative charges against the often beguiling values of a humankind "of fools and rogues, blind with superstition, tormented with envy, consumed with vanity, selfish, false, cruel, cursed with illusions-frothing mad!" (Bierce Collected Works 10: 77). Bierce's own clear-cut distinction between humor and wit should suffice here to draw a line between his approbrious aesthetics and those of the other members of the San Francisco circle:

Nearly all Americans are humorous; if any are born witty, Heaven help them to emigrate! You shall not meet an American and talk with him two minutes but he will say something humorous; in ten days he will say nothing witty; and if he did, your own, $\mathrm{O}$ most witty of all possible readers would be the only ear that would give it recognition. Humor is tolerant, tender; its ridicule caresses. Wit stabs, begs pardon-and turns the weapon in the wound. Humor is sweet wine, wit is dry; we know which is preferred by the connoisseur. (Collected Works 10: 100-1, my italics) 
In view of his tastes and literary preferences, then, it is crucial to define early in the process of reading his ingenious and vindicative sketches exactly what the object of his onslaught is. We had left the protagonist of "Chickamauga" in the introductory scenes reviving, with his wooden sword in hand, the glorious deeds of his ancestors, "as became the son of a heroic race, and pausing now and again, in the sunny space of the forest [he] assumed, with some exaggeration, the postures of aggression and defense that he had been taught by the engraver's art" (Ch 18). As the reader proceeds, he soon realizes that the author is lampooning the child's Herculean efforts to beat his invisible foes. A reference to Don Quixote and his epic battles against the windmills in La Mancha seems inevitable at this point. Bierce finds conspicuous pleasure in playing with the central character's fictitious recreations of reality. Much of the black humor in the story derives from the paradoxes and incongruities that occur when the child's idealistic conceptions are set side by side with a reality that stubbornly overturns them, as for instance when "advancing from the bank of the creek he suddenly found himself confronted with a more formidable enemy: in the path that he was following, sat, upright, with ears erect and paws suspended before it, a rabbit!“ (Ch 19).

Nevertheless, although there might be some good reasons for claiming that much of the story's effect comes from the distance in terms of knowledge of reality between an innocent child and the supposedly more experienced reader, I would also venture to assert that the highly satirical tone here finds its sources somewhere else. Bierce is not much interested in ridiculing the protagonist for the limited scope of his cognition of the universe around him; in fact the humorous touch we have pinpointed is compounded with a great deal of pathos as the child becomes the principal butt of his own obliterating visions. When he, for instance, tuns into a group of severely wounded retreating soldiers, his unexpected reactions can hardly be thought of as concocted to drive the reader into an easy guffaw:

But on and on they crept, these maimed and bleeding men, as heedless as he of the dramatic contrast between his laughter and their own ghastly gravity. To him it was a merry spectacle. He had seen his father's Negroes creep upon their hands and knees for his amusement--had ridden them so, "making believe" they were horses. (Ch 21)

What then is the object of Bierce's parody? Can it be justly reduced to the child's naïveté? I would say it cannot for, as we have made explicit above, the child does but merely echo a particular discursive practice in which he has been indoctrinated. ${ }^{17}$ It is this most powerful enemy that the author seems to direct all his efforts against. Bierce does not overtly criticize the kind of language - or should we say, semiotics - that have brought the child up into beliefs that deface history and facts, but it is clear from the way he deals with the "embodiment" of that discourse that he has entered into a raging argument with it. As Bakhtin says with reference to all parodies: ". . . he [the author] introduces into that other speech an intention which is directly opposed to the original one. The second voice, having lodged in the other speech, clashes antagonistically with the original, host voice and forces it to serve directly opposite aims. Speech becomes a battlefield for opposing intentions" ("Discourse Typology" 185). 
The satiric and the parodic modes suit perfectly Bierce's aesthetics because it is in them that dialogic imaginations find their richest soil. The author, by admitting "these Others" " utterances into his own, finds himself immersed in a never-ending crusade in which his final quest is for the limits of the meanings of those other discourses. That those limits exist is readily deduced from the metaphorical blindness from which most of the possess(ed)ors suffer. And yet, these guest languages of absences and silence can become tremendously enlightening when the intentions of the author set to work on them. Apart from being dialogic, these languages turn rebellious in extreme, as they start to question and disclaim the authority of their own creators and their origins. As Kristeva remarks in her insightful description of parody:

The exclusive situation liberates the word from the univocal objectivity, from any representative function, opening it up to the symbolic sphere. Speech affronts death, measuring itself against another discourse; this dialogue counts the person out. (81, her ${\text { italics })^{18}}^{18}$

This seems to be also Bierce's objective in his satires. His tales show frequently a Carnivalesque chaos, since it is only in the ambivalence and joyful relativity of Carnival that the boundaries of a discourse can be checked in depth. When discursive practices are given free circulation and detached from the institutions or individuals that want to elevate them to the status of Gods, we begin to see more clearly the infinite black holes behind them. Take, for example, some of the fragments of "My Favourite Murder" in which the narrator and protagonist of the story uses a religious register. Of course, knowing the ancestry and criminal life of this character, his pious vocabulary and seemingly devout attitude towards his parents must be nothing but a mask. But in Bierce, we must always bear in mind that the mask is very much the basis for the constitution of the man. Here again, discourse antecedes and anticipates behaviours and events.

The family then moved to Ghost Rock and opened a dance house. It was called "The Saints' Rest Hurdy-Gurdy," and the proceedings each night began with prayer. It was there that my now sainted mother, by her grace in her dance, acquired the sobriquet of “The Bucking Walrus." (MFM 794)

The author mocks overtly the conventionally puritan and revivalist discourses of his time by transposing them into mouths that, while echoing them, at the same time subvert their most fundamental principles. Discourse here is no longer monologic and truthbearing but, as Socratic dialogues, it destroys the naïve self-confidence of people who think that they possess some truths. Bierce uses these contemporary voices to demonstrate, often via deterritorializations, that all languages are unstable and equivocal, and that none can be granted a divine status in order to translate our experience of the world. Truths are to be sought in the dialectics of power between all these discourses. Bakhtin also proves quite conclusive on this point: 
It may be that every single-voiced and nonobjectal discourse is naive and inappropriate to authentic creation. The authentically creative voice can only be a second voice in the discourse. Only the second voice-pure relation, can remain nonobjectal to the end and cast no substantial and phenomenal shadow. The writer is a person who knows how to work language while remaining outside of it; he has the gift of indirect speech. (Qtd. in Todorov 68, his italics).

III

So far, we have seen that Bierce's art cannot be wholly appreciated if we do not include in our analyses references to the socio-cultural context in which they appear. Moreover, we have maintained that his most implacable censures were focused on the languages that different institutions used to perpetuate their hegemony. ${ }^{19}$ Evidently, Bierce was aware that the figure of the writer was also subject to the pressures of the literary canon that alternatively sanctified and condemned works according to well-established conventions. His iconoclastic drives, however, faced here a much more problematic dilemma as one cannot rebel against the system of literature by simply disregarding all its rules. The issue was now how to awaken the readers to the innumerable limitations of the sort of discourses that writers were employing at the time; hence, the stress he put on the idea of the necessity of causing an effect on his readership-paralleled perhaps only by Poe's in American literature..$^{20}$

That Bierce was more than reluctant to become a member of the circle of literary diehards in late 19th century America is well-attested by the definition he dedicated to realism in his The Devil's Dictionary:

Realism, $\mathrm{n}$. The art of depicting nature as it is seen by toads. The charm suffusing a landscape painted by a mole, or a story written by a measuring worm. (Collected Writings 276)

He exploded with incontrollable fury everytime a new Howells of a new James appeared on the literary scene as he thought of these young writers as blind believers in a poetics that, realistic as it might be, was deterring any creative innovations in the field of fiction writing. He viewed the public of his day in very much the same light as he did the rest of humanity, i.e. as too complaisant and easily taken in by a handful of "patriarchs" demarcating the literary destiny of the country. In a highly censorious essay on the realist novel, Bierce wrote: "Contemporary novels are read by none but the reviewers and the multitude-which will read anything if it is long, untrue and new enough," and a few paragraphs above, "the novel bears the same relation to literature that the panorama bears to painting. With whatever skill and feeling the panorama is painted, it must lack the basic quality in all art, unity, totality of effect" (Collected Works 10: 23, 18). As will be shown in this third section, Bierce's concern with the effectiveness of the work of art had notew orthy repercussions in all his tales. 
Bierce opened his short stories not only to the most significant voices that saturated the surrounding society but also to the reader who usually sees himself compelled to take part in the enacted dialogues. Due to the complicated structures of his narratives, the addressee needs to revise on most occasions his own generic and stylistic preconceptions. Jauss points out, in this regard, that

the historicity of literature as well as its communicative character presupposes a relation of work, audience and new work which takes the form of a dialogue as well as a process, and which can be understood in the relationship of message to receiver as well as in the relationship of question to answer, problem and solution. (8)

Thus, if the reader considers the protagonists of his tales rather pathetic figures doomed to make wrong deductions and to take infelicitous steps, he would do well to check his own competence as interpreter not to fall into those same errors. In a very conscientious manner, Bierce habitually places the addressee of his stories in a similar position to that of his personages. As Cathy Davidson cogently argues, "in all his fictions, Bierce endeavored to recreate in his readers a response that mirrors the experience of the characters. One common way of achieving that desired effect was to structure a particular story so that the protagonist's and the reader's point of view substantially coincide" (21). This is, of course, an ingenious strategy to keep the reader from being able to anticipate or to predict events. But more relevant still are other types of blanks and indeterminacies that force the reader to fill only-too-provisionally the perceptual gaps that keep getting in his way. ${ }^{21}$

In "Chickamauga," for instance, the reader needs to carry out several "willing suspensions of disbelief," if he wants to reach the last part of the story with the freshness of mind necessary to go back and see the entire narrative from the new knowledge one eventually acquires. ${ }^{22}$ The author uses the central character as main focalizer in the story, thus offering only a very slanted version of the real happenings; but, moreover, he keeps enough information up his sleeve to make the apparently objective presentation much more intriguing. The final effect of the stories depends fundamentally on this constant frustration of the reader's expectations. Language, once more, is used as a performative instrument more than a purely constative one. Bierce often tries to dismantle the principles that the recipient habitually applies in the act of reading to show that those can have very much the same consequences as the characters' hyperbiased interpretations of reality. Let me look succinctly at a passage in which the reader finds himself as disarmed in his hermeneutic struggle as the protagonist himself:

Almost within a stone's throw of where he lay they had fought a battle; but all unheard by him were the roar of the musketry, the shock of the cannon, "the thunder of the captain and the shouting." He had slept through it all, grasping his little sword with perhaps a tighter clutch in unconscious sympathy with his martial environment, but heedless of the grandeur of the struggle as the dead who had died to make the glory. (Ch 22) 
At this stage of the story, Bierce proves already straightforwardly sardonic toward the grandiloquent discourse of war-not surprisingly when the child falls asleep-but it is also clear that when this happens, the reader feels caught in a maze of questions he cannot easily answer. Why is it that the child does not hear all "the sound and the fury" of the combat? How is it that after the soldiers had retreated, a new skirmish is being fought? Why does not the child show any concern for his nearby family home? All these apparently loose ends confuse the reader to the point that he starts to doubt the adequacy of the strategies he is using to decodify the story. At this stage, one does not know any longer whether one should read it as a comic sketch, a naturalist war story, a thriller or a romance of sorts. As a result, at the close of the tale, both the protagonist and the reader come to a final realization of their shortcomings in their attempts to see and interpret reality in the correct light. ${ }^{23}$ When the child reaches his home, it is only to stand "stupified by the power of the revelation"; gone are his dreams of heroic battles when he eventually comes face to face with

the dead body of a woman - the white face turned upward, the hands thrown out and clutched full of grass, the clothing deranged, the long dark hair in tangles and full of clotted blood. The greater part of the forehead was torn away, and from the jagged hole the brain protruded, overflowing the temple, a frothy mass of gray, crowned with the clusters of crimson bubbles- the work of a shell. (Ch 23)

This clinical description of the corpse of the child's mother provides a climactic counterpoint to his innocent idealism and so, it shatters with one stroke the iconical dimension that the discourse of war had acquired in him. Nevertheless, one should not fall here into the same trap by believing that this new register is more "truthful" to the realities of war. Bierce's effectiveness derives from the continual clashes between different discourses, none of which can be granted a total hegemony over the others in his stories. It is precisely this fact that causes a feeling of restlessness also in the reader. Although there is in all of us a foucaultian "will to knowledge and truth" that keeps urging us to find a definite meaning in every speech act, in fact in Bierce's stories "truth is not born nor is it to be found inside the head of an individual person, it is born between people collectively searching for truth, in the process of their dialogical interaction" (Bakhtin, Problems 110, his italics). The reader, as the child, can only undergo a partial epiphany once all the expectations he has been accumulating through his reading are eventually upset by the closing tour de force.

The denouement of "Chickamauga" requires from the reader a revision of his own way of reading and perceiving, as he is also proved to have been duped by a peculiar treatment of literary discourse. "The child moved his little hands, making wild, uncertain gestures. He uttered a series of inarticulate and indescribable cries-something between the chattering of an ape and the gobbling of a turkey-a startling, soulless, unholy sound, the language of a devil. The child was a deaf-mute" (Ch 23). This faltering and devilish cry that brings the narrative to an end seems adequate in at least two significant ways. First, it marks the zenith of the protagonist's ritual of initiation into a new maturity in which, presumably, he will not be so easily mesmerized by any particular discursive practice any 
more. Secondly, it is a reflection of the reader's susceptibility to end up speechless when a text challenges the validity of the interpretative strategies he has been using. In this regard, many of Bierce's short stories resemble Fishian "self-consuming artifacts," for when one tries to make sense of them

[t]he result is disturbing and unsettling experience in the course of which a reader is continually revising his understanding, until, in some cases, the very possibility of understanding is itself called into question. These works, then, are self-consuming in two directions, for in the course of unbuilding their own structures, they also unbuild the structure of the reader's self-confidence. (Fish VII)

The case of "My Favourite Murder" may be even more to the point here since what we are given in this narrative is a later verbatim account of the protagonist's courtroom testimony of his uncle's murder, which ironically "by comparison" exculpates him of his mother's. The effect of the text on the reader is here quite the opposite of the one in "Chickamauga" as he is deliberately estranged from both action and character by the impersonal way in which events are reported. However, this story-within-the-story frame serves well Bierce's intention of foregrounding the discourse level and gives to the tall-tale grotesqueries in the narration a petty relevance in comparison. The reader often needs to use a dubious double standard in his attempts to find in the discourse of the I-narrator that extenuating evidence that would justify his reprehensible deeds. Hence, the recipient tends to evaluate language "extensionally" and, consequently, to prove more lenient in his judgments when, for example,

"One morning I [the protagonist] shouldered my Winchester rifle, and going over to my uncle's house, near Nigger Head, asked my Aunt Mary, his wife, if he were at home, adding that I had come to kill him. My aunt replied with her peculiar smile that so many gentlemen called on that errand and were afterward carried away without having performed it that I must excuse her for doubting my good faith in the matter. She said I did not look as if I would kill anybody, so, as a proof of good faith I leveled my rifle and wounded a Chinaman who happened to be passing the house. She said she knew whole families that could do a thing of that kind, but Bill Ridley was a horse of another colour. (MFM 795-96)

Once more, the tongue-in-cheek satire of this unmistakenly Biercean passage results from the detachment and unaffectedness with which the happenings are presented. Likewise, the ambivalent fashion in which sociological and religious cant is manipulated adds tension to the language and problematizes some deeply-rooted myths.

But what is truly essential in this tale is that one progressively comes to realize that events have not really "preceded" the meanings that the discourse is now bringing home to the reader, but rather the opposite. As Culler concludes in his enlightening discussion of Freud's analysis of Oedipus: "Instead of the revelation of a prior deed determining meaning, we could say that it is meaning, the convergence of meaning in the narrative discourse, that leads to posit this deed as its appropriate manifestation" (174). This inversion of the two traditional narrative levels, i.e. the fabula and the sjuzhet of the 
Russian Formalists, obliges the reader to revise the logics of his analysis and to grant more importance to the discursive practices of man in any type of causal sequence. ${ }^{24}$ This way Bierce's stories test the readers' skills to transgress the narrow margins that the literature and language of realism were canonizing in this period. His definition of "logic" in The Devil's Dictionary questions quite explicitly the validity of the perceptual processes of man in their inevitable discursive preconceptions:

Logic, $n$. The art of thinking and reasoning in strict accordance with the limitations and incapacities of the human misunderstanding. (Collected Writings 294)

From this new point of view, the reader may even come to agree with the protagonist of "My Favourite Murder" when he claims that "in point of artistic atrocity [his] murder of Uncle William has seldom been excelled" (MFM 800). Naturally, it is the mechanical and almost formulaic repetition of his deeds in his ulterior recitation that the "artistry" and the motivation of the crime surface. His discourse, more so than his actions, make us aware of the inaccuracy of his obtuse (mis)understanding. And yet, as remarked above, we may even be brought to sympathize with him as our own meanings and evaluations are likely to be put to trial in the never-ending process of dissemination and reification of discourse. Bierce's greatest accomplishment, then, needs to be sought in his insights into the impossibility of a purely realistic and "truthful" use of language. There is always in it a treasure to be dug up. The closing quotation below by Foucault adumbrates cogently this same idea by establishing the emptiness of all discourses until a subject charges them with significance:

It seems to me that the theme of the founding subject permits us to elide the reality of discourse. The task of the founding subject is to animate the empty forms of language with his objectives; through the thickness and inertia of the empty things, he grasps intuitively the meanings lying within them. Beyond time, he indicates the field of meanings-leaving history to make them explicit-in which propositions, sciences, and deductive ensembles ultimately find their foundation. In this relationship with meaning, the founding subject has signs, marks, tracks, lettres at his disposal. But he does not need to demonstrate these passing through the singular instance of discourse. (227-28)

\section{Notes}

1. For the most extensive and well-informed accounts of Bierce's war years, see McWilliams, as well as Fatout, Ambrose Bierce. Other useful contributions dealing with Bierce's innate qualifications in the military art are Wilt, Weimer and Fatout, "Ambrose Bierce Writes about War."

2. For two representative works showing this reinterpretation of language, see Foucault (The Archaeology 215-37), and Said (Orientalism).

3. My use of the concept of "the Other" here coincides broadly with Jacques Lacan's understanding of the term. Lacan explains that "the Other as previous site of the pure subject of the signifier holds the master position, even before coming into existence, to use Hegel's term 
against him, as absolute Master. For what is omitted in the platitude of modern information theory is the fact that one can speak of the code only if it is already a code of the Other, and that is quite different from what is in question in the message, since it is from this code that the subject is constituted, which means that it is from the Other that the subject receives even the message that he emits" (Ecrits 305).

4. As I argue here, examples of commentaries in which the emphasis falls upon his criticism of the referential world are abundant. I quote at some length below a passage from Mencken's representative remarks: "Out of the spectacle of life about him he got an unflagging and Gargantuan joy. The obscene farce of politics delighted him. He was an almost amorous connoisseur of theology and theologians. He howled with mirth whenever he thought of a professor, a doctor or a husband. His favorites among his contemporaries were the zanies, a Brian, Roosevelt or Hearst" (210).

5. For an illuminating discussion on this issue, see Culler (169-87). He claims here that "positing the priority of events to the discourse which reports or presents them, narratology establishes a hierarchy which the functioning of the narratives subverts by presenting events not as givens but as the products of discursive forces or requirements" (172). See also Chatman.

6. See Bakhtin (Problems of Dostoevsky's) and Jauss (Toward an Aesthetic). Other volumes by these authors will be also referred to, but these two remain their most programatic ones.

7. See Foucault (The Archaeology) and Kristeva. Kristeva's comments on Mennipean discourse are applicable to Bierce's own: "Its discourse exteriorizes political and ideological conflicts of the moment. The dialogism of its words is practical philosophy doing battle against the idealism and religious metaphysics, against the epic. It constitutes the social and political thought of an era fighting against theology, against law" (83-84, her italics).

8. Edward Said's understanding of texts corroborates our own. As he declares at the outset of one of his insightful books: "My position is that texts are worldly, to some degree they are events, and even when they appear to deny it, they are nevertheless a part of the social world, human life, and of course the historical moments in which they are located and interpreted" (The World 4).

9. The catalog of writers one could list here is far too long and diversified, yet the inclusion of a few crucial figures such as Clemens, Howells, Norris, Garland or Stephen Crane should be enough to give us an idea of the paramount importance that journalism had as a launching platform for most of the authors of this generation.

10. See Bakhtin, The Dialogic Imagination 263, $411 \mathrm{ff}$.

11. Ambrose Bierce (The Collected Writings 18). Hereafter, all quotations from Bierce's stories will be indicated by the initials of the tales' titles and the page reference in this edition, e.g., (Ch 18).

12. See Michel Foucault ("What is an Author?") and Edward W. Said ("The Ethics of Language").

13. For the best selections of Bierce's journalism so far edited, see Hopkins, and Berkove.

14. See Austin (How to Do Things 53-93) and Searle (Speech Acts 137-40), who deal in great detail with the possibilities of performative utterances in language.

15. See Barthes $(S / Z$ 4-9).

16. For two remarkable studies of Bierce as part of this important tradition, see Martin, and Field.

17. Kernan follows Dryden in affirming that satire does not habitually prey on individuals: “... true satire, as distinct from lampoon and libel, must grow not from personal animus but from a pereeption of a moral failing, and must not be directed toward an individual but toward vice and folly" (The Plot 14). 
18. Cf. Foucault (Language, Counter-Memory 29-52), where he brilliantly discourses on the problems of limits and transgression.

19. See Gramsci (The Prison Notebooks). Gramsci's understanding of "hegemony" is particularly productive because it includes and transcends both the cultural and the ideological.

20. For two comparative studies that place Bierce in a neo-romantic tradition in American fiction, see Hayden, and Miller.

21. I borrow the concept of "textual indeterminacies" here from the works of Wolfgang Iser. See especially Iser (The Implied Reader 274-94).

22. Evidently, my understanding of the phrase "willing suspension of disbelief" differs from Coleridge's original one. Iser, on the other hand, seems to come closer to my own use of the phrase: "the 'willing suspension of disbelief' will apply, not to the narrative framework set up by the author, but to those ideas that had hitherto oriented the reader himself. Ridding oneself of such prejudices--even if only temporarily-is no simple task" (The Act of Reading 8).

23. Davidson supports very much the same hypothesis in her perceptive revision of Bierce's narrative strategies: "The ending, then, plays two tricks: one on the child and one on the reader. Like the child, the reader suddenly learns he has not occupied some privileged position. Indeed, the double epiphany puts the reader in a situation analogous to that of the child. The reader, too, has unknowingly and with full confidence in his interpretative skill, been enacting this story only to find that crucial information has been withheld" (The Experimental Fictions 44).

24. One cannot omit here a reference to Nietzsche's memorable discussion on the operational reordering of the sequence pain-mosquito as mosquito-pain in his Werke 3: 804-5.

\section{Works Cited}

Austin, John L. How to Do Things with Words. Cambridge: Harvard UP, 1962.

Bakhtin, Mikhail. The Dialogic Imagination: Four Essays by Mikhail Bakhtin. Ed. Michael Holquist. Austin: U of Texas P, 1981.

. "Discourse Typology in Prose." Readings in Russian Poetics: Formalist and Structuralist

Views. Eds. Ladislav Matejka and Krystyna Pomorska. Ann Arbor: U of Michigan P, 1978.

. Problems of Dostoevsky's Poetics. Ed. and trans. Caryl Emerson. Minneapolis: U of

Minnesota P, 1984.

Barthes, Roland. S/Z. Trans. Richard Miller. New York: Farrar, Straus and Giroux, 1974.

Bellamy, Edward. Looking Backward. New York: New American Library, 1960.

Berkove, Lawrence I., ed. Skepticism and Dissent: Selected Journalism from 1898-1901. Ann Arbor: Delmas, 1980.

Berthoff, Warner. The Ferment of Realism: American Literature 1884-1919. Cambridge: Cambridge UP, 1981.

Bierce, Ambrose. The Collected Works of Ambrose Bierce. New York: Neale, 1909-12. 1960.

The Collected Writings of Ambrose Bierce. Ed. Clifton Fadiman. New York: Citadel,

Chatman, Seymour. Story and Discourse: Narrative Structure in Fiction and Film. Ithaca: Cornell UP, 1978.

Culler, Jonathan. The Pursuit of Signs: Semiotics, Literature, Deconstruction. Ithaca: Cornell UP, 1981.

Davidson, Cathy N. The Experimental Fictions of Ambrose Bierce: Structuring the Ineffable. Lincoln: U of Nebraska P, 1984. 
Fatout, Paul. Ambrose Bierce: The Devil's Lexicographer. Norman: U of Oklahoma P, 1951. “Ambrose Bierce Writes about War." Quarterly News Letter 16 (1951): 71-75.

Field, B. S. Jr. "Ambrose Bierce as a Comic." Western Humanities Review 31 (1977): 173-80.

Fish, Stanley. Self-Consuming Artifacts: The Experience of Seventeenth-Century Literature. Berkeley: U of California P, 1972.

Foucault, Michel. The Archaeology of Knowledge and the Discourse of Language. Trans. A. M. Sheridan. New York: Pantheon, 1972. . "Preface to Transgression." Language, Counter-Memory, Practice. Ed. and trans. Donald F. Bouchard. Ithaca: Cornell UP, 1977.

. "What is an Author?" Bulletin de la Société Francaise de Philosophie 63.3 (1969): 73104.

Frost, Robert. New Enlarged Anthology of R. Frost's Poems. Ed. Louis Untermeyer. New York: Washington Square, 1971.

Frye, Northrop. Anatomy of Criticism: Four Essays. Princeton: Princeton UP, 1957.

Gramsci, Antonio. Selections from the Prison Note-Books of Antonio Gramsci. Ed. Quintin Hoare and Geoffrey N. Smith. New York: International Publishers, 1971.

Hayden, Brad. "Ambrose Bierce: The Esthetics of a Derelict Romantic." Gypsy Scholar 7 (1980): 3-14.

Hopkins, Ernest J., ed. The Ambrose Bierce Satanic Reader: Selections from the Invective Journalism of the Great Satirist. New York: Doubleday, 1967.

Howells, William D. A Traveller from Altruria. New York: Hill and Wang, 1957.

Iser, Wolfgang. The Implied Reader: Patterns of Communication in Prose Fiction from Bunyan to Beckett. Baltimore: Johns Hopkins UP, 1974.

.The Act of Reading: A Theory of Aesthetic Response. Baltimore and London: The Johns Hopkins UP, 1978.

Jauss, Hans Robert. "Literary History as a Challenge to Literary Theory." New Literary History 2 (1970): 7-37.

Toward an Aesthetic of Reception. Trans. Timothy Bakhti. Minneapolis: U of Minnesota P, 1982.

Kernan, Alvin B. The Plot of Satire. New Haven: Yale UP, 1965.

Kristeva, Julia. Desire in Language: A Semiotic Approach to Literature and Art. Ed. Leon Roudiez. New York: Columbia UP, 1980.

Lacan, Jacques. Ecrits: A Selection. Trans. Alan Sheridan. New York: Norton, 1977.

Martin, Jay. "Ambrose Bierce." The Comic Imagination in American Literature. Ed. Louis D. Rubin, Jr. New Brunswick: Rutgers UP, 1972. 195-205.

McWilliams, Carey. Ambrose Bierce: A Biography. New York: Boni, 1929.

Mencken, H. L. Prejudices: Sixth Series. New York: Knopf, 1927.

Miller, Arthur M. "The Influence of Edgar Allan Poe on Ambrose Bierce." American Literature 4 (1932): 130-50.

Neale, Walter. Life of Ambrose Bierce. New York: Walter Neale, 1929.

Nietsche, Friedrich. Werke. Ed. Karl Schlechta. Munich: Hanser, 1956.

Said, Edward W. "The Ethics of Language." Diacritics 4 (1974): 28-39.

Orientalism. New York: Pantheon, 1978.

The World, the Text, the Critic. Cambridge: Harvard UP, 1983.

Searle, John R. Speech Acts: An Essay in the Philosophy of Language. Cambridge and New York: Cambridge UP, 1969. 
Todorov, Tzvetan. Mikhail Bakhtin: The Dialogical Principle. Trans. Wald Godzich. Minneapolis:

U of Minnesota P, 1984.

Twain, Mark. A Connecticut Yankee in King Arthur's Court. New York: Bantam, 1981.

Weimer, David R. "Ambrose Bierce and the Art of War." Essays in Literary History. Eds.

Rudolph Kirk and C. F. Main. New York: Russell, 1964. 229-38.

Williams, Raymond. Marxism and Literature. Oxford: Oxford UP, 1977.

White, Allon. "Bakhtin, Sociolinguistics and Deconstruction." The Theory of Reading. Ed. Frank

Gloversmith. Brighton: Harvester, 1984.

Wilt, Napier. “Ambrose Bierce and the Civil War." American Literature 1 (1929): 260-85.

\section{Departamento de Filología Inglesa UNIVERSIDAD DE ALICANTE}

\section{Working Papers}

A Profile of the Motivation of Spanish Pre-University

Students in the Learning of English

José Castro Calvín

The Dichotomy between Public and Private in the British Intellectuals of the $30 \mathrm{~s}$

Silvia Caporale Bizzini

Series edited by José Mateo Martínez, Celia Rico Pérez, and M. Carmen África Vidal 